\title{
Factors Affecting the Quality of Concrete Containing Solar PV Cells through Taguchi Method
}

\author{
An Cheng ${ }^{1}$, Hui-Mi Hsu ${ }^{1}$, a , Sao-Jeng Chao ${ }^{1}$, Jia-Ruey Chang ${ }^{2}$, Li-Wei Teng ${ }^{3}$, Sung-Ching Chen ${ }^{3}$ \\ ${ }^{1}$ Dept. of Civil Engineering, National Ilan University, Yilan 260, Taiwan \\ ${ }^{2}$ Center for Sustainable Development, National Ilan University, Yilan 260, Taiwan \\ ${ }^{3}$ Dept. of Harbor and River Engineering, National Taiwan Ocean University, Keelung 202, Taiwan
}

\begin{abstract}
In order to comply with the implementation of sustainable development, the construction industry through the use of less polluting green energy technology is already imminent and more had to do. Production of Portland cement consumes large amount of energy and releases lots of carbon dioxide, nevertheless, the developing of sustainable society means more urgent and important to search for new cementitious materials to replace Portland cement in future constructions. The research employs Taguchi method to identify the key factors influencing the performance of alkali activated silica fume concrete in which amorphous silicon solar cells are ground and added into the mixture. Taguchi method has made valuable contributions to statistics and engineering. It provides techniques for investigating variation in experiments, system, parameter and tolerance design, all of which have been influential in improving manufactured quality. The conclusions were made thru ANOVA and F-test based on the statistical analyses. Next, we expect the inconsistence observed in the study to be further resolved by Grey Relational Analysis which is a normalization evaluation technique to solve the complicated multi-performance characteristics optimization effectively.
\end{abstract}

\section{Introduction}

Due to environmental and chemical factors, concrete structures undergo a number of degradation processes during their life cycles [1-3]. Hence, how to reduce the degradation of concrete has become a key issue to ensure concrete quality. Alkali-activation of slag, fly ash and other alumino-silicate materials have been intensively investigated during the last decades [4]. In comparison with conventional Portland cement-based composites these materials offer excellent durability in chemically aggressive environment, high compressive strength, lower basic creep, or environmental benefits. The objective of this paper is to identify the key factors influencing the performance of alkali activated silica fume concrete in which amorphous silicon solar cells are ground and added into the mixture the properties of alkali-activated materials in solar PV cells.

$90 \%$ of the solar cells on the market today are made of silicon and $95 \%$ of silicon based solar cells on the market are comprised of crystalline silicon. There are two types of crystalline, namely monocrystalline, also called single crystalline, and polycrystalline, also known as polysilicon. Besides these, another up and coming type of solar cell is the thin film solar cell with a fast growth rate. By year 2011, the thin film solar cell industry represented about $5 \%$ of all cells on the market. Thin film technology using various PV substances, including amorphous silicon, cadmium telluride, copper indium and gallium selenide. Each kind of material is suitable for different solar applications. Traditionally thin film solar cells made out of amorphous silicon are used for smaller-scale applications, including things like travel lights, pocket calculators, and camping gear used in remote locations. In Taiwan, the used thin film solar cells only made out of the amorphous silicon can be disposed as nonhazardous wastes like glass in a way of burying it into a waste landfill or adding it into outdoor tiles.

In previous studies [5-8], we had demonstrated the study results of general quality of concrete blended with waste solar PV cells. The use of ground solar cells on the mechanical properties and durability of concrete has been investigated. This research attempts further to identify the key factors influencing the quality of alkali activated concrete containing the ground amorphous silicon solar cells. The assessment of an optimal mixture for desired quality is an important issue in the field of material engineering. Therefore, the design of experiments (DOE) is critical to identify the quality and characteristics of materials within limited time and cost. Utilization of Taguchi method is to minimize the experiment number using standard orthogonal array and Signal to Noise ratio $(\mathrm{S} / \mathrm{N})$.

\section{Experiments}

\footnotetext{
a Corresponding author: hmhsu@niu.edu.tw
} 
1. Compressive strength test: Compressive strength testing is crutial to understand the stength capacity of a concrete specimen. Compressive strength test of the specimens is conducted according to ASTM C109-13【Standard Test Method for Compressive Strength of Hydraulic Cement Mortars】 with a specimen size, $50 \times 50 \times 50 \mathrm{~mm}$.

2. Resistivity test: Surface resistivity measurement may provide very useful information about the state of a concrete structure. It has been proven to be directly linked to the likelihood of corrosion and the corrosion rate, and there is a direct correlation between resistivity and chloride diffusion rate and even to determination of early compressive strength. Concrete resistivity measurements on cylindrical test samples with a size of $100 \times 200 \mathrm{~mm}$ performed with the four-point Wenner array probe technique

3. Water absorption test: Absorption can be described as the ability to take in water by means of capillary suction. As such, water absorption has been used as an important factor for quantifying the durability of cementitious systems. Water absorption was made in accordance with ASTM C642-13 【 Standard Test Method for Density, Absorption, and Voids in Hardened Concrete 】 with a cylinder size of $100 \times 50 \mathrm{~mm}$.

4. Permeability test: The water permeability of concrete at the surface is a key factor in determining the durability of concrete structures. A reliable permeability test of the concrete cover is therefore crucial, namely the CRD-C48-92 standard test method for water permeability of concrete with a cylinder size of $100 \times 50 \mathrm{~mm}$.
In Taguchi method, $\mathrm{S} / \mathrm{N}$ ratio is used to measure the deviation of the quality characteristics from the desired value. The $\mathrm{S} / \mathrm{N}$ ratio for each process parameter is calculated based on $\mathrm{S} / \mathrm{N}$ analysis function. A larger $\mathrm{S} / \mathrm{N}$ ratio is normally consistent with better quality characteristics. Quality characteristics can be divided into larger-the-better (LTB), smaller-the-better (STB), and nominal-the-best (NTB). This study set compressive strength and resistivity as an LTB characteristic Eq. 1 and water absorption and permeability as STB characteristics Eq. 2 in the investigation of single quality characteristics. 1. LTB S/N ratio: This is applicable for quality characteristics that are better when bigger.

$$
S N_{L T B}=-10 \log \left(\frac{\sum_{i=1}^{n} \frac{1}{y_{i}^{2}}}{n}\right)
$$

2. STB S/N ratio: This is applicable for quality characteristics that are better when smaller.

$$
S N_{S T B}=-10 \log _{10}\left(\bar{y}^{2}+S_{n}^{2}\right)
$$

\section{Orthogonal array}

An orthogonal array is used to reduce the number of experiments, and thus, overall costs. To determine the multi-quality characteristics, this study adopted the materials used in previous studies [5-8] as the control factors in experiments. At such, a full factorial experiments with seven control factors \& three levels as shown in Table 1 would produce Taguchi's orthogonal array with only 18 experiments and then corresponding responses to each of these factors were then analyzed.

\section{Taguchi method}

Table 1. Designation of 7 control factors and 3 factor levels.

\begin{tabular}{|c|c|c|c|c|}
\hline \multicolumn{2}{|c|}{ Control factors } & Level 1 & Level 2 & Level 3 \\
\hline A & Fineness & Not thru \#325 & Thru \#325 & - \\
\hline B & Water-binder ratio & 0.4 & 0.5 & 0.6 \\
\hline C & Superplasticizer & $0.8 \%$ & $0.4 \%$ & None \\
\hline D & $\begin{array}{c}\text { Silica fume material } \\
\text { type }\end{array}$ & Silica fume & Fly ash & $\begin{array}{c}\text { Amorphous } \\
\text { silicon }\end{array}$ \\
\hline E & Cement replacement & $5 \%$ & $10 \%$ & $20 \%$ \\
\hline F & Alkaline activator & None & NaOH+Na2CO3 & $\mathrm{KOH}$ \\
\hline G & Curing condition & Air & $\begin{array}{c}\text { Steam } 2 \text { days }+ \\
\text { Saturated } \mathrm{Ca}(\mathrm{OH}) 2\end{array}$ & $\begin{array}{c}\mathrm{Saturated} \\
\mathrm{Ca}(\mathrm{OH}) 2\end{array}$ \\
\hline
\end{tabular}

\section{Analysis of variance}

The use of $\mathrm{S} / \mathrm{N}$ ratios provides only the degree of influence that the factor levels exert on the experiment. However, analysis of variance (ANOVA) enables a further evaluation of the contribution of each factor and 
determines its importance. ANOVA and F-test were performed to statistically see the control factors significant process and percent contribution to the experiment. In the process, the $\mathrm{S} / \mathrm{N}$ ratio sum of squares for each factor is determined to calculate the betweengroup variability and then F-test and contribution ratio can be calculated, respectively [9].

\section{Results}

The contributions and the associated results of the control factors for each one of experiments are listed in Tables 2 and 3, respectively.

Table 2. Results of contribution ratio.

\begin{tabular}{|c|c|c|c|c|}
\hline Control factor & $\begin{array}{c}\text { Compressive } \\
\text { strength test(\%) }\end{array}$ & $\begin{array}{c}\text { Resistivity } \\
\text { test(\%) }\end{array}$ & $\begin{array}{c}\text { Water absorption } \\
\text { test(\%) }\end{array}$ & Permeability test(\%) \\
\hline A & 0.03 & 0.00 & 0.00 & 0.00 \\
\hline B & 53.75 & 53.67 & 59.72 & 62.39 \\
\hline C & 5.05 & 4.93 & 1.62 & 2.09 \\
\hline D & 0.12 & 4.69 & 2.50 & 1.51 \\
\hline E & 5.32 & 5.77 & 3.53 & 1.49 \\
\hline F & 28.72 & 17.09 & 24.20 & 20.14 \\
\hline G & 0.48 & 4.23 & 1.50 & 0.44 \\
\hline Error & 6.51 & 9.61 & 6.93 & 11.95 \\
\hline Total & 100 & 100 & 100 & 100 \\
\hline
\end{tabular}

Table 3. Summary of results

\begin{tabular}{|c|c|c|c|}
\hline Experiment & $\begin{array}{c}\text { The best experiment } \\
\#\end{array}$ & Contribution ratio & The best combination \\
\hline $\begin{array}{l}\text { Compressive } \\
\text { strength test }\end{array}$ & \multirow{4}{*}{$\begin{array}{c}\text { Exeriment } 1 \\
\mathrm{~A}_{1} \mathrm{~B}_{1} \mathrm{C}_{1} \mathrm{D}_{1} \mathrm{E}_{1} \mathrm{~F}_{1} \mathrm{G}_{1}\end{array}$} & $\mathrm{~B}>\mathrm{F}>\mathrm{E}>\mathrm{C}>\mathrm{G}>\mathrm{D}>\mathrm{A}$ & $\mathrm{A}_{2} \mathrm{~B}_{1} \mathrm{C}_{1} \mathrm{D}_{1} \mathrm{E}_{1} \mathrm{~F}_{1} \mathrm{G}_{3}$ \\
\hline Resistivity test & & $\mathrm{B}>\mathrm{F}>\mathrm{E}>\mathrm{D}>\mathrm{C}>\mathrm{G}>\mathrm{A}$ & $\mathrm{A}_{1} \mathrm{~B}_{1} \mathrm{C}_{1} \mathrm{D}_{2} \mathrm{E}_{1} \mathrm{~F}_{1} \mathrm{G}_{3}$ \\
\hline $\begin{array}{c}\text { Water absorption } \\
\text { test }\end{array}$ & & $\mathrm{B}>\mathrm{F}>\mathrm{E}>\mathrm{D}>\mathrm{C}>\mathrm{G}>\mathrm{A}$ & $\mathrm{A}_{2} \mathrm{~B}_{1} \mathrm{C}_{1} \mathrm{D}_{1} \mathrm{E}_{1} \mathrm{~F}_{1} \mathrm{G}_{3}$ \\
\hline Permeability test & & $\mathrm{B}>\mathrm{F}>\mathrm{C}>\mathrm{E}>\mathrm{D}>\mathrm{G}>\mathrm{A}$ & $\mathrm{A}_{2} \mathrm{~B}_{1} \mathrm{C}_{1} \mathrm{D}_{2} \mathrm{E}_{1} \mathrm{~F}_{1} \mathrm{G}_{3}$ \\
\hline
\end{tabular}

\section{Conclusions}

In this article we demonstrated the study results of factors affecting the Quality of Concrete Containing Solar PV Cells through Taguchi method. The research had identified the key factors influencing the performance of alkali activated silica fume concrete in which amorphous silicon solar cells are ground and added into the mixture. The conclusions were made thru ANOVA and F-test based on the statistical analyses. The observations were fourfold as follows. Firstly, control factors (A) fineness seems to give no contribution to those tests at all. Secondly, the first experiment denoted as gave the best performance among all the 16 predefined experiments for all those of 4 tests. Thirdly, contribution ratios and the best factorial combination of seven control factors \& three levels for each of those 4 tests were determined, respectively. Finally, both control factors (A) fineness and (D) silica fume material type gave the inconsistent levels as shown in those best factorial combinations. As in next study, we expect the inconsistence to be further resolved by Grey Relational Analysis which is a normalization evaluation technique to solve the complicated multi-performance characteristics optimization effectively. 


\section{References}

1. M.H. Zhang and O.E. Gjorv, Effect of silica fume on pore structure and chloride diffusivity of low porosity cement pastes, Cement Concrete Res. 21(6) (1991)1006

2. S. Mindess, J.F. Young and D. Darwin, Upper Saddle River, Prentice Hall, NJ, USA, 2003

3. R.L.A. Male, Pore structure and permeability of cementitious materials, Mater. Res. Soc. Symp. Proc. 137 (1988)403-410

4. J. Provis and J. van Deventer: Geopolymers: structures, processing, properties and industrial applications, Woodhead Publishing Ltd., Oxford, UK, 2009

5. L.W. Teng, R. Huang, H.M. Hsu, A. Cheng, J.R. Chang and P.H. Yu; Strength Quality Research of
Cement Mortar Blended with Solar PV Cells, Adv. Mater. Res. 1025-1026 (2014)1025-1030

6. S.C. Chen, R. Huang, H.M. Hsu, L.W. Teng and Y.P. Lai, Durability Quality Research of Cement Mortar Containing Solar PV Cells, Adv. Mater. Res. 10251026 (2014)1020-1024

7. S.C. Chen, R. Huang, H.M. Hsu, J.R. Chang and L.W. Teng, Strength Quality Research of Concrete Blended with Solar PV Cells, Adv. Mater. Res. 1061-1062 (2015)392-395

8. C.Y. Chang, R. Huang, P.C. Lee and T.L. Weng, Application of a weighted Grey-Taguchi method for optimizing recycled aggregate concrete mixtures, Cem. Concr. Compos. 33 (2011)1038-1049

9. S.Y. Zou, R. Huang, M.C. Chi and H.M. Hsu, Factors Affecting the Effectiveness of Inorganic Silicate Sealer Material through Multi-Quality Characteristics Materials, 6(3)(2013)1191-1204 